\title{
WestVirginiaUniversity
}

THE RESEARCH REPOSITORY @ WVU

Graduate Theses, Dissertations, and Problem Reports

2008

\section{From the Forest to the Rose}

Veronda G. Carey

West Virginia University

Follow this and additional works at: https://researchrepository.wvu.edu/etd

\section{Recommended Citation}

Carey, Veronda G., "From the Forest to the Rose" (2008). Graduate Theses, Dissertations, and Problem Reports. 1924.

https://researchrepository.wvu.edu/etd/1924

This Thesis is protected by copyright and/or related rights. It has been brought to you by the The Research Repository @ WVU with permission from the rights-holder(s). You are free to use this Thesis in any way that is permitted by the copyright and related rights legislation that applies to your use. For other uses you must obtain permission from the rights-holder(s) directly, unless additional rights are indicated by a Creative Commons license in the record and/ or on the work itself. This Thesis has been accepted for inclusion in WVU Graduate Theses, Dissertations, and Problem Reports collection by an authorized administrator of The Research Repository @ WVU. For more information, please contact researchrepository@mail.wvu.edu. 


\title{
FROM THE FOREST TO THE ROSE
}

\author{
Veronda G. Carey \\ Thesis submitted to \\ the College of Creative Arts \\ at West Virginia University \\ in partial fulfillment of the requirements \\ for the degree of
}

Master of Fine Arts

in

Acting

Jessica D. Morgan Bishop, M.F.A., Chair

Jerry McGonigle, M.F.A.

Lee Blair, M.F.A.

Department of Theater and Dance

Morgantown, West Virginia

2008

Keywords: Another Part of the Forest, Mary Rose, Outcome

Copyright 2008 Veronda G. Carey 


\section{ABSTRACT \\ From the Forest to the Rose \\ Veronda G. Carey}

This thesis will examine the methods implemented to expand the minor character role of Coralee from Lillian Hellman's Another Part of the Forest and the minor character role of Mrs. Otery from J.M. Barrie's Mary Rose. The thesis will also include performance challenges faced and review the experience of working with contrasting directing methods. 


\section{TABLE OF CONTENTS}

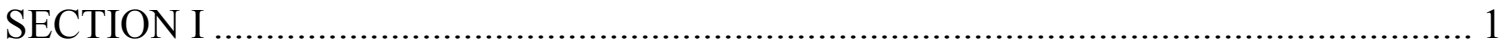

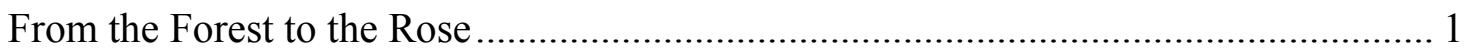

Creating Coralee ............................................................................................. 2

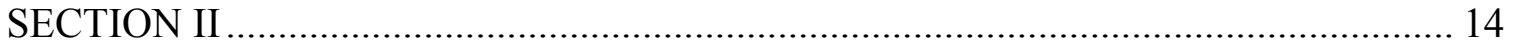

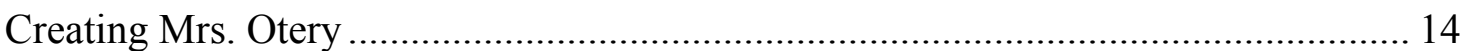

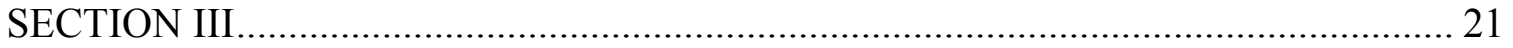

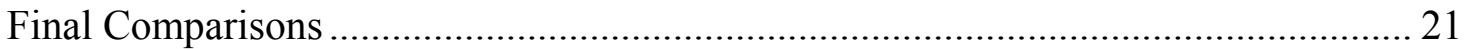

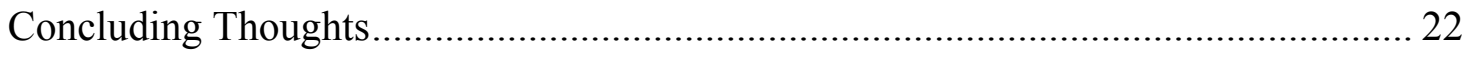

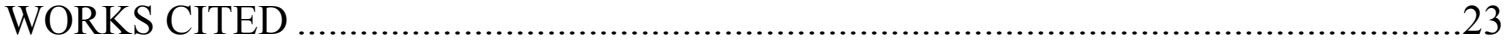




\section{SECTION I}

\section{From the Forest to the Rose}

There is no cure for the disease I have. It's been a part of my system for as long as I can remember. There are times when the intensity of this plague burns like the passion between two lovers, or simmers in the nerves of my skin like warm jambalaya sitting on the stove. Like many ailments it has side affects, takes twists and turns from the route of expected travel, and even has periods of remission. The consolation I carry with me allowing me to enjoy the presence of this infection in my system is that many people around the world are afflicted in the same way while others enjoy its' emotional impact. Doctors have no name for it but in the world of performing arts, it is referred to as acting.

Uta Hagen refers to the Presentational actor as one who "attempts to reveal human behavior through a use of himself, through an understanding of himself and consequently and understanding of the character he is portraying," (Hagen 12). While I wouldn't have been able to word it so eloquently when I entered Graduate school training three years ago, this is the very concept I realized I needed guidance in achieving. I wanted to perform in this manner at a more consistent level, although, I am well aware that it is a never-ending process. While the Representational style of acting defined by Hagen is one who "deliberately chooses to imitate or illustrate the character's behavior" works for some, habitually it creeps into my work if I am experiencing a detachment from the character internally (Hagen 11). It has often served me in getting a character from one destination to the next within the story but without the colorful scenery that 
makes the ride a more enriching experience. I find Representational acting a stumbling block for me on the road to exploring the internal workings of characters from or living in worlds outside of the environment I occupy or am originally from.

The 2007 Fall Main stage performance season at West Virginia University provided me the opportunity to analyze both styles and how they affect my work in a way more memorable than I have had the opportunity. The characters I portrayed and their given circumstances were polar opposites. This thesis project is intended to compare and contrast the process of developing two dramatic performance roles.

\section{Creating Coralee}

Another Part of the Forest is an epic drama written by Lillian Hellman. It is the prequel to Hellman's very successful play, The Little Foxes. The story is based on the fictional Hubbard family “... of New Orleans at the turn of the century as they scramble for the means to prop up their declining fortunes, revealing rivalries and disloyalty in a lacerating power struggle," (The American Guide 5). The action of Another Part of the Forest begins twenty years before with the Hubbards in Bowden, Alabama during the summer of 1880 . They are a prime example of what could be called an early American dysfunctional family. However, the drama is grand in the scenic display of financial comfort attained by the head of the family Marcus Hubbard, its rich dialogue, and in the creative way Hellman keeps the personal wedges between the family members to the forefront in spite of all the other weighty issues presented in the play.

Take for instance the picture that may capture the eyes of the audience members when they enter the theater.

The portico leads into the living room by back center French doors. On the right side of the portico is an old wing of the house. An exterior staircase to this wing 
leads to an upper porch off which are the bedrooms of the house and behind the staircase are the back gardens and kitchen quarters. Under the second story porch is a door leading to the dining room of the house, and a back door leading to the kitchen. The other side of the portico leads to a lawn which faces the town's main street. The main part of the house, built in the 1850's is Southern Greek (Another Part of the Forest 307).

In the West Virginia University stage production, the set of this stationary home not only consumed the entire floor space but also seemed to reach up into the rafters. Anyone knowing my taste in plays would have thought this one to be a dream comes true for me to be a part of. I love the stage environment of a home. Yet when I joined the cast, it was certainly not out of the desire to do so.

Another Part of the Forest begins fifteen years after the abolishment of slavery in this country. The role of Coralee, which I was asked to play, represents part of what became of the first generation of people freed from the degrading system that was in place. Transitional periods of any kind can present difficulties to the people and/or institution(s) involved. "In many parts of the South, the newly freed slaves labored under conditions similar to those existing before the war," (Thomas). There was limited protection offered to former slaves and Andrew Johnson, Abraham Lincoln's successor, sympathized with the southern states allowing his appointees to form proslavery governments (Thomas). "The new state legislatures passed laws designed to keep blacks in poverty and in positions of servitude. Under these so-called black codes, ex-slaves who had no steady employment could be arrested and ordered to pay stiff fines," (Thomas). I found these facts about the period to be valuable information to assist me in creating Coralee's possible life and mental state before the Hubbard family purchased their home in Bowden because the play does not provide a great deal of insight into Coralee's personal history. She is written as a minor character. 
Previously I alluded to the fact that when the option to play the role was presented to me by the director, Professor Jerry McGonigle, I did not accept happily. Well, that is indeed the truth. One might ask why I would make mention of a seemingly negative detail. Simply put, it marks the beginning of my journey with the character.

The play itself can be somewhat difficult to stomach because of the openly racist remarks imbedded within the plot that reflect the majority's ideology at the time. Moreover, the action is taking place during the post-civil war period. The AfricanAmerican population in West Virginia is tremendously small especially on campus. To be a part of the culture being thought of or treated by other characters on stage as substandard humans in this kind of environment caused me to become uneasy. I was meditating over questions such as: Why was this play chosen? What kind of impact will it have on the audience, particularly my students? In an environment that lacks diversity, how will I able to allow this role to speak beyond a stereotype?

My initial agreement to participate was based on the following two reasons: I wanted to work with Jerry McGonigle again, and Hellman's story is not only compelling but well told. Walking away from good directors and good stories is not a habit I wanted to start.

The delayed decision to be a part of the project and Coralee having a condensed written presence in the play fed my approved absence from the table readings. As I waited to be called into the rehearsal process, I isolated Coralee. I put her in a mental box and didn't plan on thinking much about her until it was absolutely necessary. It was as if she was a distant cousin I only reunited with at family functions. She caused me a 
sort of creative depression because I didn't find her challenging and ultimately didn't feel I would be respected by playing her. No matter, I knew I had to.

The earliest rehearsal that I recall being involved in was taking place in the Gladys G. Davis Theater as opposed to our smaller rehearsal space. It was the first time I can recall coming into a rehearsal totally off-book. The fact that there was only one line in the scene helped of course. The other players cheered for me because I was able to leave so quickly. They probably didn't know how useless I felt (talent wise) or how I was using humor to cover the resentment I felt within me about the script. I didn't want to bring into the space what I learned later was an expected negative attitude because of the content. The following week my outlook began to change.

McGonigle invited a professor from the history department to sit in on the last part of our rehearsal and talk about the period of the play with the group. I can't recall if he specialized in African-American history or not but either way he was definitely qualified. It was arduous to sit through his presentation of the facts. I didn't object to the information he was giving, I just slowly began to realize I was sitting with a group of people who were hearing a lot about the history of Southerners and African-Americans for the first time. This was evident in the way other cast members responded to the particulars he made mention of and I became uncomfortable.

The situation raised the following two questions for me: Why don't they know as much about my culture as I do about theirs? Can they understand and learn from the serious ramifications the themes within the play have had on our society or, from their perspective; will this just be a play? 
Information that I took for granted as common knowledge was new for a number of other cast members. For instance, the professor felt the play propagated the idea that Southern white women of wealth were often victimized by their husbands. He emphasized that not only were they of an elite class, in general, they were brazen manipulators as shown in the character of Regina. Overall, these women were made to feel as though they were the best women created. This misconception still causes divisions in our present day society.

Looking back I suppose I shouldn't have been surprised that people younger than me and predominately white were learning new things about this particular point in time. After all, I have been taught African-American history throughout my education and I have learned from my African-American peers that everyone doesn't have that opportunity. A lot of it depends on what school districts a person spent their elementary years in. Also, it wasn't until the most recent years in my life that I have experienced the aftershocks of the slavery period personally.

The professor discussed the intimacy that existed between the black and white cultures despite the dehumanization of, racist activity towards, and physical abuse of black people. This time I watched individuals react to hearing the word intimacy. This foundation between the two groups is warped and phenomenal. They were living and breathing together for centuries prior to when the play begins. Unfortunately, one group was exploiting the other in their position of power but both were the main components in the economic expansion of this country. "The wealth of the United States in the first half of the $19^{\text {th }}$ century was greatly enhanced by the labor of African Americans," (Wikipedia 1). 
The professor talked about the intimacy going beyond an economic need. At this point in his discussion he gave a lot of evidence of how blacks were generally viewed by whites on a personal level. I wanted to stop listening. I would compare the feelings I was experiencing to the kind a person may have when watching a movie that covers a subject matter too sensitive for comfort. The unpleasant emotions are provoked because the issues are still in existence and yet, for the most part, they were discussed as problems of the past. There we were gathered together in a state where just a few weeks prior a black woman was abducted, held hostage and tortured by six white people. Granted, these individuals were obviously disturbed and most, if not all, involved had a prior criminal record. However, it is important to note that according to the victim's statements, the primary motivation for the crime was racial. Things were said and done to her that are supposedly no longer part of our reality.

Turning this around in my mind added to my anxiety about performing this type of role in an environment where I am a minority in every way. I saw my role in this play as representing everything thought to be negative by the majority in the post civil war period. I would symbolize the nigger, the former slave, a person thought to have no more value than that of a work horse at a time when it was alright for the ignorant to be proud of their ignorance. I went home that night really wanting to tell Professor McGonigle to find someone else. I went into my closet and came across a video; a documentary on the concentration camps. I started thinking about every film that I had seen that focused on the Jews and what they went through under Hitler's rule. Those thoughts reminded me of all the films I had seen on slavery. Roots came to mind because I had recently seen members of the cast on some award show being honored for the anniversary of the film. 
Suddenly, I stopped worrying about what others would think of Coralee and put a lot more thought into how I saw her. While it remained true that she was not going to say much at all let alone anything that would let you get to know her, I decided that accepting her into my cannon of roles would teach me humility as an actress. Why should I run from portraying her in any environment? Plenty of actors have taken on the emotional burden of giving life to the horrors of concentration camps, plantations, and Middle Eastern war torture scenarios.

Their willingness to do so has given us great insight to ourselves as a society and proven that every horrifying incident has the aptitude to teach. One could say they prove any sentiment that resembles the biblical scripture at Jeremiah 10:23 where it says, "It does not belong to man who is walking even to direct his step." Mankind has proven that it has a way of dominating itself to its own injury but from these incidences we have the opportunity to learn and grow. One of the places that we condense these situations into a learning format is inside of the theater. I enjoy being a part of this medium. Coralee was not written for glamour but for an audience to get a sense of something real, something personal from amidst the larger plot lines.

Now it was time to dig in. I worked on pushing my emotions down and finding what I liked about Coralee. I wanted to make sure I stayed away from anything stereotypical or that didn't come from my own bag of skills when building her character. On the surface, Coralee could have easily been presented as a reincarnation of the Hattie McDaniel's character of Mammy from Gone With the Wind. Ms. McDaniel was criticized by Blacks for perpetuating the mammy caricature. She responded this way: Why should I complain about making seven thousand dollars a week playing a maid? If I 
didn't, I'd be making seven dollars a week actually being one," (Jim Crow 5). The line between limited choices and the only choice is very thin.

Many Black actors at this point in time, me included, have a great deal of respect for those who put their foot in the door even though the position may have been painful. The caricature of Mammy, however, was indeed more fiction than real.

From slavery through the Jim Crow era, the mammy image served the political, social, and economic interests of mainstream white America. During slavery, the mammy caricature was posited as proof that blacks - in this case, black womenwere contented, even happy, as slaves. Her wide grin, hearty laughter, and loyal servitude were offered as evidence of the supposed humanity of the institution of slavery (Jim Crow 1).

Documented evidence shows that it wasn't until after Emancipation that Black women began running White households or occupying any special position (Jim Crow 2).

Lillian Hellman was born in New Orleans, Louisiana. She spent half of each year in New Orleans in a boarding home run by her aunts and the other half in New York (Wikipedia). Another Part of the Forest was first produced in 1946. She was a product of the Jim Crow era and very familiar with the mores of the South. Hellman's creation of Coralee is more spot on when it comes to depicting a Black woman living and working in that time undoubtedly because of her background. Still it was going to be a challenge to avoid a caricature having limited dialogue.

I began with Coralee's vocal sound and speaking pattern. Professor Laura Hitt, our vocal instructor, spent a great deal of time with us during a rehearsal discussing the vocal sounds of the Deep South. These sounds were specific to the period of the play. I was dismayed for a period of this session because we met in a large groups and I worried that there wouldn't be anything shared specific to Black speech. I was just basing this on the fact that a lot of what you hear of early American Black speech is contrived. To my 
relief, Ms. Hitt had sound bites fitting for my culture and station. She went further to suggest that I listen to the Black actress in To Kill A Mockingbird. This was a great resource!

I felt that Coralee had to speak in a manner that incorporated a few considerations. The first was her relationship with the family, the second was how her own culture would be speaking, and the third was who she was speaking to. Coralee's backstory is not provided in great detail except for knowing her age (45) and the fact that she came with the family to the new house where the action of the play begins.

Therefore, she has been in close enough company with them to have some of her sounds affected by their station. This would no doubt slightly augment her pronunciation as well. Coralee also associates differently with each member of the family, even if it's without words. I wanted to convey vocally how she felt about the person with whom she was speaking.

In the case of Ms. Vinny, who she cared for a great deal, I tried to stress the elongation of the vowels to increase the breathiness of my sound. I would describe the sound as if a person was attempting to hug someone with their words. I spoke with Marcus verbally and nonverbally with respect. This wasn't because I feared him. It was because I respected his views of people, the war, and how he treated me. However, I certainly did not care for how he treated Ms. Vinny. As a result, my tone and movement with him was always direct. As far as Regina was concerned, I was the most ethnic and commanding when speaking to her. Her attitude did not stop me from developing a motherly relationship with her. The liberal mind of Marcus Hubbard and the benevolent love of Ms. Vinny allowed the dynamics of our rapport to flourish without interruption. 
I would like to take this time to expound further on the back story I created for Coralee. I took into consideration all of my research over the period when comprising it. Coralee would have more than likely been born a slave. I decided on how she came to be with the Hubbard family after a conversation with Alex Palowski who played Marcus Hubbard. We came to the conclusion that he purchased Coralee and her family when she was a young girl, and by the time the war ensued, he had probably given them their freedom. Coralee was kept on as hired help. This would have been a smart move on her part because she was already accustomed to the Hubbard family and employment meant protection.

I would not be able to move forward in discussing character development without mentioning my thoughts on Coralee's movement. I kept in mind her main duty in this play and that was caretaker of a house with a great number of people in it. I modeled her after any efficient housewife. I had to be quick and free-flowing. Her movement needed to indicate that she knew the house so well she could maneuver in it competently even if she were blind. When standing still, I made sure my feet were firmly planted to avoid any sign of weakness. Coralee has a strong presence that is youthful despite her years.

I was not able to completely embody Coralee until the week of final rehearsals. Although I was learning to enjoy her, I still felt as though I was filling in as an extra and not truly making a connection with story due to my emotions. This was not the case in my rehearsal work with the actress playing Ms. Vinny, Tammy Hoier. I enjoyed doing my scenes with her because they truly dealt with the simplicity and honesty of communication. Their relationship was also the physical realization of what the historian 
was speaking of when it came to the intimacy between the two races. Although Ms. Vinny had status over Coralee, at some point, human frailty equalizes everyone.

A funny thing started happening in final rehearsals. I spent a lot of time watching the play from the audience perspective. As I watched, it was if I had started playing a game with my character. I kept noticing scenes that Coralee could appear and be useful to the story although she was not necessarily written in to do so. It was at this point in the project where I really began to appreciate McGonigle's openness as a director.

I have worked with him before, but our work for this role was limited because of the minor character status. I appreciated the observation he made of my energy and awareness in the scene with Miss Vinny. Hearing it forced me to log it in as reminder to maintain that sense of being alive for my fellow actress in the scene, Tammy, throughout the run. It was a crucial scene for her character. McGonigle is very good at letting actors find their way into the skin of their characters and being a gentle guide. Well, there I was finding my way in a manner that he could have deemed was disrupting how he saw the picture frames of the play forming. Kindly, he indulged me.

The more I found for Coralee to do on stage, the more playing her excited me. I had not spoken in any detail with my director about the emotional disturbance I was dealing with. This increased activity was assisting me in completely pushing that to the side. I was now giving her more depth which had been my greatest desire from the beginning. Coralee was listening in on confidential conversations, directing activity in the home, and becoming a more three dimensional contrast to the racist views of some of the characters in the play. 
Again, these cameo appearances were not written in. My favorite additional moment happened when the entire Hubbard family was out on the patio area of the stage entertaining guests. Oscar Hubbard's girlfriend was exchanging some heated words with his father and I took advantage of this moment to show Coralee's chemistry with the family. I walked into the moment with a set of full punch glasses ready to serve but made an instantaneous turnabout to the exit when I realized something disrespectful was being said to Mr. Hubbard.

Working with the other actors in Another Part of the Forest was more complex off stage than on. Earlier I mentioned there was an expected negative attitude on my part. Well, I learned that the actors who had characters that made racial slurs throughout the script were having an exceptionally hard time because of my presence. They expected me to display some ill will towards them. The actor playing Oscar, John Harper, would apologize to me constantly when he came backstage. He let me know early in the process it was hard enough to play a person with these kinds of issues, but to have a friend present and listening that is from the African-American culture made him a little ill. I found that others were being particularly attentive to me seemingly out of guilt.

The idea of them doing so tickled me because I had been so wrapped up in my own feelings I didn't think about what they were dealing with. I did my best to put them at ease and reminded them that sometimes the stories we tell are tough, however, they need to be told. Our final product will hopefully educate, inspire a higher consciousness, and entertain those watching. I did greatly appreciate their sensitivity.

I have spoken of my director previously but I would like to reiterate that his willingness to allow me to explore where I fit into pieces of the puzzle was also greatly 
appreciated. I began to think of Coralee as a character that completed pictures and/or through lines. I was proud to hear McGonigle's feedback. One of his summation statements was that he felt Coralee grounded the play. I even relished in the way he interrelated my Coralee to the Where's Waldo game. McGongile told me, "At a certain point, you just never knew when she was going to show up. I couldn't wait to see where she would pop up next." When the show closed after its' two week run, I was drained.

\section{SECTION II}

Creating Mrs. Otery

There was no time to rest. I moved right from Another Part of the Forest into rehearsals for Mary Rose. I was very much excited about being involved with this project. This play is set in England in 1919. I had just spent my summer in England working at a fringe theater in an Assistant General Manager position. I had research coming out of my ears!

I mentally consumed everything I could while I was there as far as the culture, speech patterns, and accents were concerned. I was mesmerized by fantastic shows executed by a cultural range of actors-most of who were English. When I returned to the states, I was dying to work with an English accent on stage! First of all, my trip had affected my own accent so I thought it would be fun to have an excuse to keep it.

Second, this accent isn't one that I have seen a lot of African-American actors have the opportunity to use on stage and I found it a challenge in the classroom.

The Mary Rose auditions stood out to me. I remember being called in by Professor Lee Blair (the director) to read and not being able to drop the accent even 
though he requested that we not attempt any particular accent. I wasn't trying. It was a natural side affect of my summer. That aside, the reading went well. I came away feeling that I had given the director things he was looking for. I was reading for the part of Mrs. Otery and some of the narration included in the stage directions. At the time, Blair thought he might extend the character by allowing her to narrate. Oddly, a different type of creative lightening bolt struck him in auditions. He asked several people, me included, to read the narrative lines-some together, some apart. I could see what he was trying to figure out and I could also tell he was excited by the answer he received from watching us work.

There was no surprise to me when I saw the casting list now included a chorus not originally part of the script. I was happy that I was listed as Mrs. Otery and very curious to see Blair's vision become a reality.

The table readings were the main format in which we discussed the period of the play. Mary Rose is a three act play first produced in 1920 and written by J.M. Barrie. We talked a lot about the author and how his tumultuous upbringing served as fuel for his plays. Barrie's brother died when he was seven years old in a skating accident. This tragic incident caused his mother to go into a deep depression and thereby neglect her other children. "Barrie tried to gain her affection by dressing up in the dead boy's clothes," (Books \& Writers). This attempt to please her influenced the rest of his life.

Barrie was obviously deeply connected to the idea of a child losing his or her own identity and/or never growing up. This theme shows up in his most popular work of Peter Pan but also in Mary Rose. Mary Rose is a fantasy play where parents search for their lost child. Mary Rose was first lost on the Island That Likes to be Visited for thirty 
days. When she is found, she doesn't seem to have any idea that any significant amount of time has passed nor does she seem to be aging. Later in the play, she is lost on the island once more after becoming a wife and a mother. This time she returns to her family's home after twenty-five years. Mary Rose looked just the same as she did when disappeared only to die shortly after her arrival-apparently from the shock.

Whether or not it was Barrie's intent for Mary Rose to be assumed dead is a debatable point among critics of the play. It was even an issue that Blair grappled with up until our first table reading. However, it was then that he announced his decision for us to play the idea that she dies at the end of Act II and reappears in Act III as a ghost. Personally, I always liked the idea of not defining the end of the play for a certainty. The script is ambiguous at times. Barrie likes the idea of children escaping and I would like to think that Mary Rose escaped back to the island for safety and when she made a final return home her family had gone.

The rest of my personal research on facts provided within the text consisted of reviewing my photos of English homes. I also found additional ones actually taken at the turn of the century or a least of manor homes existing at that time. These were important for me to view because my character is the caretaker of the Morland family home. I find that the spaciousness and high ceilings of most of the homes lend to the creepy feel undermining the story. When I examined pictures of the period clothing, I was relieved to find out the costumer for the show was not requiring me to wear a corset. They are restrictive when it comes to breath and didn't want to have to worry about that along with maintaining the consistency of my vocal changes. 
Just as with Coralee, I began working on Mrs. Otery by developing her vocal sound and speech patterns. I realized this is where I often begin as an actress. She would be more of a challenge for me in this area than Coralee but not as difficult a process as it would have been before I traveled to England.

My concept of Mrs. Otery was developed through the given narration and discussions with Blair. I figured she was widowed and from another region in England than where she is currently working at the time of the play. She talks about being told the stories of the family from people in the village. "It's little I know. They were gone before my time. The old man and his wife, they grew too frail to live alone ... if they're still alive," (Mary Rose 64). It would be logical that an outsider would now be caring for the showing of the home to potential buyers. If she had known the family personally, heard the rumors of the girl or been able to support herself otherwise, she would have no doubt abandoned the position by the time she meets Harry, Marry Rose's adult son.

I thought of her as a person trapped based on circumstance. In our production, her anxiety and nervous tension was heightened not just by Mary Rose's presence in the house but also by The Visitors, the title given by Blair to the additional actors giving voice to the narration of the play. This idea worked really well. The Visitors weren't just narrators but people from the island that Mary Rose kept getting lost on. All of them had names and back stories developed by the actors playing the roles. Mary Rose and I were the only two characters who could see them. My rationalization for this was that they were in the house to bring Mary Rose back to the island and no one who had not been lost there would be able to see them. Although they have been trying for a while, they have been unsuccessful and revealed themselves to Mrs. Otery hoping she would help 
them in achieving their goal. Their world, being beyond her understanding, does nothing but frighten her, causing her to live in a cocoon of denial and avoidance. Overall, I was attempting to give her a cold veneer. This was easier said than done.

I knew her speech pattern had to be sharp and direct. I wanted to speak with speed while still conveying clear thoughts and articulating well-a trait quite common among English speakers from Great Britain. I listened to Paul Meier's English Accent and Dialect CD and sound bites from the IDEA website repeatedly. I enjoyed watching films such as Sense and Sensibility and Love Actually in order to watch body movements that accompanied common sounds.

The latter is a more contemporary film but helped me for when I wanted to relax Mrs. Otery a little more in Act III. I had to pay close attention to not allow Cockney sound changes to creep into my accent. We were shooting for Standard British English and Cockney sounds seem to come easier to me or I should say are easier to maintain. It was pointed out to me by our voice coach that I was holding the General American sound on words like can't and pass. I was proud to now be able to hear the adjustments that needed to be made in my speech and make them without confusion.

I wasn't overly concerned about the movement of Mrs. Otery. The period of the play, the environment, and Mrs. Otery's clothing influenced whatever choices I made. The fact that Mrs. Otery was aware that The Visitors or Mary Rose could show up at any time dictated that I move almost as quickly as I spoke-often in direct lines. I pulled at my clothing (my shawl in particular) a lot to allude to the climate in the house and my need to feel safe despite my rough exterior. 
The cast received notes on period movement and the one thing I did understand is that Mrs. Otery was no lady. "A lady should be quiet in her manners, natural and unassuming in her language, careful to wound no one's feelings, but giving generously and freely from the treasures of her pure mind to her friends," (Period Movement Packet 6). Mrs. Otery was the complete opposite of most of these requirements when dealing with Harry and fought to maintain some code of manners as a hostess. I found myself accomplishing a lot in understanding why she behaved as she did but I was struggling to embody her complete personality.

I wasn't nailing what Professor Blair referred to as her icy persona so that I would have a complete contrast from the end of the play when Mrs. Otery has a bit of breakdown. The rehearsal process aided me in ultimately achieving this more than my private work. I spent most of my time in the early rehearsal with Professor Blair and Vance Barber who played Harry. I adored this time. I had wanted to work with Vance for a long time. He is a senior B.F.A. student-a factor that makes working together slim to none. I adore his instincts on stage and his ability to communicate well with other actors-a facet of our work not to be taken for granted.

In Mary Rose, our characters begin the action of the play. During the period of rough blocking, Vance and I tried several relationship possibilities. There were times when he flirted and I would accept or reject his advances. At other times, he played the lost boy to my protective mother persona. In one rehearsal, he exuded the cold exterior while I maintained a more endearing quality. It was a fun process but frustrating when we realized that certain actions would serve where we were in the story but not necessarily where we were going. 
The presence of The Visitors became another challenge. We had to factor in when and if we could see them. Blair gave us a lot of playing room which I appreciated. He scheduled a couple of rehearsals with just me and Vance in which we discussed our association with them and with each other. These talks and scene rehearsals really helped me to fill out the skin of Mrs. Otery. I was starting to discover she wasn't as tough as she appeared to be but something between me and Vance still needed to click.

Every rehearsal, Blair would say I was getting closer but no cigar, so to speak. It had nothing to do with my speech or movement. The problem was wrapped up in my intent. I could never seem to come off cold enough. I wasn't capturing that Mrs. Otery cared more about leaving than who bought the house or selling it for that matter. In Cat On A Hot Tin Roof, the character of Brick talks about waiting for the click in his head that will give him peace of mind. That is the same click actors wait for-except the click achieves connection to the character-a heartfelt connection to the character and situation. From my recollection, Vance and I heard the click right around the same time.

It was the night before dress rehearsals. Vance and I got into this discussion about something I hadn't let sink in before that night. Our characters while in the same story as the other characters were outside of the story because of the time lapses in the play. We were disconnected by Barrie from the rest of the play's action. It made us feel separate from the cast and awkward in relating to each other.

I began to reason that it didn't matter what happened to everyone else for us-our scenes stood alone. I had been approaching our scene in the final act as if we were starting over without realizing it. In actuality, it was more like someone pushing the pause button in our conversation. Together Vance and I decided that this sense of us 
being alone, having only each other, needed to be alive in play. Wow! That was a very beneficial observation and conversation for two actors to make and have.

We clicked! Our connection and/or communication with each other and The Visitors increased at least ten fold. Vance even engaged me physically more forcing the fear of my character to come to the surface. More importantly, I was able to accomplish the icy drive of Mrs. Otery. It was apparent from the moment I met Harry because now I had a clearer understanding of where it was coming from. I was trying to pull the motivation from Harry when it was really coming from the presence of The Visitors and the need my character had not to explain them. Like dancing partners, we truly became in tune with each other's rhythm and appreciated the way we each kept building (finding new things) to the end of the run.

\section{SECTION III}

\section{Final Comparisons}

Ultimately the outcome of the creations of these two characters was the same. In my opinion, they were successfully formed and well executed for the duration of the dramatic presentations. With more time in performance, I'm positive that additional layers to them both would have continued to materialize.

The journey of their development however was widely divergent. Coralee came out of an emotional struggle, history, and my personal connection to the culture. These aspects made my relationship with the play as an actress one of obligation and not artistic growth. I now have a clearer idea of what I can contribute to a script that does not give a character I may be playing a three-dimensional voice. The relationship I had with 
Professor McGonigle was totally about support. He gave me room to play and full control of my character and any choices I made for her. It takes an astute director to know when to do that. While I am still not in full agreement with the choice of material for this venue, I have great respect for the artistic style and commitment Professor McGongile has for painting a clear picture of the writer's intent.

I had a more technical approach to Mrs. Otery who I was more excited to play simply because she was English. I focused more on her as an artistic challenge. I enjoyed the obscure world that she was living in and had a much easier time immersing myself in it. Professor Blair and I had what I consider a more traditional relationship between an actor and director. He shaped the frame and I played within those angles. Both directors gave very positive feedback during the run of the shows.

\section{Concluding Thoughts}

The trip from the Forest to the Rose was memorable and educational for me as an artist and a person. I will work to allow the beneficial discoveries I made while working on the these two projects to influence my future performance choices as an actress and the way I approach theater education as an instructor 


\section{WORKS CITED}

Barrie, J. M. Mary Rose a Play in Three Acts. London: Samuel French, Ltd., 1924.

Hellman, Lillian. Another Part of the Forest. New York: Random House, Inc., 1979.

Bible. Jeremiah. Trans. New World Bible Translation Committee. New York: Watchtower Bible and Tract Society of New York, Inc., 1984.

Pilgrim, David. "Jim Crow." Museum of Racist Memorabilia. (October 2000): n. pag. Online. Internet. www.ferris.edu/jimcrow/mammies/ 4 April 2008.

“J.M. Barrie (1860-1937)." Books and Writers. (2002): n. pag. Online. Internet. www.kirjasto.sci.fi/jmbarrie.htm 14 April 2008.

"Lillian Hellman." Wikipedia, American Theater Guide. n. pag. Online. Internet. www.answers.com/topic/lillian-hellman?cat=entertainment 14 April 2008.

"Slavery in the United States." Wikipedia, The Free Encyclopedia. n. pag. Online. Internet. http://en.wikipedia.org/wiki/History_of_slavery_in_the_United_States 3 April 2008.

Thomas, Sandra. "Abolitionist/Editor-A Biography of the Life of Frederick Douglass. Online. Internet. www.history.rochester.edu/class/douglass/part5.html 4 April 2008. 